\title{
Transfer of cases from the International Criminal Tribunal for Rwanda to Domestic Jurisdictions
}

\author{
Alex Obote-Odora* \\ Legal Consultant in International Criminal Law and Procedure, International Humanitarian Law \\ and International Human Rights Law, Stockholm, Sweden
}

\begin{abstract}
The article examines Rule 11 bis on the transfer of cases from the Rwanda Tribunal to domestic jurisdictions. It discusses the criteria for transfer under Rule 11 bis and reflects on reasons for the denial of all the Prosecutor's requests for transfer except in the recent Uwinkindi's Appeals Chamber decision. The article also examines how the Appeals Chamber resolved the ambiguity between the Death Penalty Law vis- $\dot{a}$-vis Imprisonment in Isolation in Munyakazi, on the one hand, and ambiquity in Article 59 of the Rwanda Code of Criminal Procedure ("RCCP") vis-à-vis Articles 13(10) and 25 of the Transfer Law, on the other hand, opening the way for the transfer of Uwinkindi to Rwanda. The article recognizes the high standards the Appeals Chamber has established for the transfer of cases to domestic jurisdictions and notes that only few States satisfactorily meet these requirements. In sum, the article welcomes the Uwinkindi decision and recognises a positive development in international criminal law and procedure. However, it also cautions that in practice the precedent may not necessarily translate into a flood of cases being transferred to Rwanda because many States will not be able to meet the Rule 11bis high international standards.
\end{abstract}

\section{Keywords}

International Criminal Tribunal for Rwanda (ICTR); Rule 11bis; Legal framework; adequate penalty structure; Fair Trial Rights; protection of defence and prosecution witnesses; suitability of detention facilities; monitoring trials of transferred cases; Revocation of Rule 11 bis transferred cases

\section{Introduction}

This article provides an overview of the Rule 11 bis jurisprudence in the International Criminal Tribunal for Rwanda ("the Tribunal" or "ICTR") as of 31 December 2011. It examines Trial and Appeals Chamber decisions and considers challenges the Prosecutor encounters in his requests for transfer of cases from the

*) E-mail: alex.odora@gmail.com. LL.B. (Hons), Makerere University, Kampala, Uganda; Post-Graduate Diploma in Legal Practice, Law Development Centre, Kampala, Uganda; LL.M. Public International Law, and LL.D. International Criminal Law (Stockholm, Sweden). Obote-Odora was a lecturer in law (Bar Course) at Law Development Centre, Kampala, Uganda, Faculty of law at Stockholm University and the Department of law at the University of Swaziland. He was also, inter alia, State Advocate in the Office of the Director of Public Prosecution, Ministry of Legal Affairs, Republic of Zambia. At the United Nations, he was Chief of Appeals and Legal Advisory Division, Office of the Prosecutor, International Criminal Tribunal for Rwanda. He was called to the Uganda Bar in January 1977. 
Tribunal to national jurisdictions, including Rwanda. In this introductory section, the article outlines the Rule 11bis process by identifying the requirements necessary for a successful transfer of cases. An important requirement is for a designated Trial Chamber to determine whether a State to which the Prosecutor seeks to transfer a case has a legal framework which criminalizes the alleged conduct of the accused and provides an adequate penalty structure.

Section two examines in more detail two critical conditions that the receiving States must meet. First, the State must have jurisdiction, and second, it must be capable of rendering a fair trial. Subsumed under these two conditions are several related issues that include conditions of detention; protection of defence and prosecution witnesses, the right of free movement for defence counsel and their staff, as well as provision for the monitoring of trials by independent monitors who are appointed by the Prosecutor.

Section three discusses the Uwinkindi decision which, at the time of writing, was the only successful request by the Prosecutor for the transfer of a case from the Tribunal to Rwanda. The case is particularly significant because, after denials of several prior requests, it was the first time the Tribunal ordered a senior genocide-era official to be tried in Rwanda. On 23 January 2012, after the 16 December 2011 Uwinkindi decision, Canada extradited Leon Mugesera, a Rwandan who had been living in Quebec, Canada since 1992; Mugesera is alleged to have incited Hutus to commit genocide and crimes against humanity through his speeches and writings in 1992. There is optimism that, because of the Uwinkindi decision, many more fugitives will be deported to face trial in Rwanda and that many more ICTR cases will be transferred to the East African nation pursuant to Rule 11bis. Concluding remarks are in section four.

\subsection{The Rule 11 bis Process}

The objective for the transfer of cases from the ICTR to domestic jurisdictions is to reduce its workload and subsequently facilitate the closing of the Tribunal, consistent with the United Nations Security Council-mandated Completion Strategy. The transfer of cases to domestic jurisdictions is necessary because the United Nations Security Council ("the Council") established the ICTR as a temporary court with limited jurisdiction. Its mandate is to prosecute only persons most responsible for international crimes committed in Rwanda in 1994. Because persons 'most responsible' for genocide in Rwanda are very many - indeed the numbers go into several thousands - the ICTR, as a temporary court, would not be able to investigate and prosecute all persons most responsible for the 1994 genocide. Additionally, the ICTR Statute is silent on the time-line for the closure of the ad hoc tribunal. ${ }^{1}$

1) UNSC Res 955 (8 November 1994) UN Doc. S/RES/955. 
The Council adopted resolutions $1503(2003)^{2}$ and $1534(2004)^{3}$ outlining the completion strategy for the two Tribunals. In both resolutions, the Council urged the International Criminal Tribunal for the former Yugoslavia ("ICTY") and the ICTR to expeditiously work towards closing the tribunals. However, the Council did not provide specific dates when the two Tribunals should close. Later, the Council adopted resolution 1966(2010) ${ }^{4}$ and established an International Residual Mechanism ("the Mechanism") to manage the formal closure of the ICTY and ICTR.

The Mechanism has two branches: the ICTR and the ICTY. The ICTR branch is scheduled to become operational from 1 July 2012 and that of the ICTY from 1 July 2013. The Mechanism shall continue the jurisdiction of the tribunals and to respect the rights of the accused as stipulated in the ICTR and ICTY Statutes and Rules of Procedure and Evidence ("the Rules").

Article 1 of the Mechanism stipulates that the Mechanism shall continue the territorial, temporal and personal jurisdiction of the ICTR as set out in the ICTR Statute. ${ }^{5}$ Article 5 of the Mechanism provides for concurrent jurisdiction to prosecute persons covered by Article 1 of the ICTR Statute and, the Mechanism, like the ICTR, has primacy over national courts. Article 6 of the Mechanism provides pre-requisites for the referral of cases to national jurisdictions. In sum, the Mechanism retains all the major provisions of the ICTR Statute. A fundamental difference is that the Mechanism provides for transfer of cases to domestic jurisdiction in Article 6 of its Statute, while the ICTR does so in its Rule 11bis of the Rules.

Therefore, the Mechanism, like the ICTR, will have authority to refer cases from the ICTR to domestic jurisdictions. Similarly, a State seeking to try an indicted accused must satisfy the Mechanism that it will meet the standards and thresholds for the transfer of cases as developed by the ICTR jurisprudence. After a case is referred to a domestic jurisdiction, the ICTR will retain, at any stage of the procedure, the right to formally request a national court to defer the case in accordance with the ICTR Statute and its Rules. The process of deferral may be initiated by a motion filed by the Prosecutor or proprio mutu by the Chamber.

The authority to revoke a reference is based on Article 8 of the ICTR Statute which gives a supervisory role to the Chambers over the conduct of cases before national courts. And, pursuant to Article 8 of the ICTR Statute, the judges adopted Rule 11bis to regulate the process for transfer of cases from the Tribunal to domestic jurisdictions. Rule 11 bis also establishes standards for fair trial of the referred cases and a monitoring system to ensure that national courts comply with the thresholds of the ICTR when prosecuting serious international crimes.

\footnotetext{
2) UNSC Res 1503 (28 August 2003) UN Doc.S/RES/1503.

3) UNSC Res 1534 (26 March 2004) UN Doc.S/RES/1534.

4) UNSC Res 1966 (22 December 2010) UN Doc.S/RES/1966.

5) Ibid. See also Articles 1 to 7, ICTR Statute annex to UNSC Res 955 (8 November 1994) UN Doc. S/RES/955.
} 
The judges also set conditions when referred cases may be deferred to the ICTR in situations when national courts fail to comply with the standards and thresholds laid down by the ICTR.

Rule 11 bis provides that once an indictment is confirmed, whether or not the accused is in the custody of the Tribunal, a Trial Chamber, at the request of the Prosecutor, may determine if the particular case may be referred to the authorities of a State. ${ }^{6}$ Such a State may include one in whose territory the crime was committed, one in which the accused was arrested or, one with jurisdiction and that is willing and adequately prepared to accept such a case. ${ }^{7}$ The Trial Chamber may also order such a referral proprio motu, after having given the Prosecutor and the accused, if in the custody of the Tribunal, the opportunity to be heard. ${ }^{8}$ Overall, the judges must be satisfied, prior to ordering the referral, that the accused will receive a fair trial in the courts of the State concerned and that the death penalty will not be imposed on the accused, if convicted. ${ }^{9}$

The scope of application of Rule 11 bis is limited to persons whose indictments have been confirmed by a Trial Chamber. The Prosecutor is at liberty, without a court order, to transmit files of suspects who are not indicted to a national prosecution authority for further investigations and prosecution. Within the Office of the Prosecutor ("OTP"), the use of the term 'transfer of cases' is limited to the transfer of cases of indicted persons authorised by the Chamber under Rule 11bis of the Rules from the ICTR to a domestic jurisdiction. On the other hand, when investigatory case files of unindicted persons are transferred by the Prosecutor to a national jurisdiction, the term used is 'transmission'. The distinctions assist in avoiding confusion of the two processes.

With respect to transmission of investigatory case files by the Prosecutor to a national jurisdiction, the law is silent on whether the Chambers may exercise any supervisory role on the Prosecutor's decision for ensuring that it complies with international standards and thresholds of the ICTR jurisprudence as is evolved and developed through its case law. On the other hand, the Prosecutor also recognized that investigatory case files are not cases before the Chambers until confirmation of indictments. To that extent, case files transmitted by the Prosecutor to domestic jurisdictions do not fall within the jurisdiction of the Tribunal. However, while there are no explicit criteria regulating the transmission of investigatory case files to domestic jurisdictions, the Prosecutor cannot be seen to ignore the guidelines provided in Rule 11 bis and blindly transmit investigatory case files to domestic jurisdictions simply because the cases are not before the ICTR. This

\footnotetext{
6) Rule 11 bis (A) of the Rules.

7) Ibid.

8) Rule 11 bis (B) of the Rules.

9) Rule 11 bis $(\mathrm{C})$ of the Rules.
} 
limitation on the authority of the Prosecutor to transfer, or to transmit cases, is generally recognized. ${ }^{10}$

It is not surprising therefore that the Prosecutor proactively put in place a process for the responsible transmission of such investigatory case files to domestic jurisdiction under his overall prosecutorial discretion with the objective to ensure that domestic courts comply with international standards in the prosecution of international crimes. ${ }^{11}$ The Prosecutor also retained the responsibility to monitor trials of cases resulting from the investigatory case files transmitted to domestic jurisdictions, including Rwanda, and to further determine whether such trials comply with international standards. Finally, the Prosecutor does retain the right to recall the file if the national prosecution authority fails to meet international standards in the prosecution of persons whose files are transmitted to domestic jurisdictions.

With respect to cases that are before the Tribunal, prior to submitting an indictment to the Chamber for confirmation, the Prosecutor also puts in place criteria for the selection of cases for prosecution ensuring, among other things, that perpetrators represent, as much as is practically possible, the geographical spread of Rwanda. The reasoning underpinning this policy is that it will avoid the unnecessary perception that only persons from certain geographical areas of Rwanda were responsible for the genocide. ${ }^{12}$ Thus, some accused persons who should otherwise have been prosecuted by the Tribunal, consistent with this policy, were instead identified as good candidates for referral to Rwanda.

The authority of the Chambers to order transfer of cases to national jurisdiction, and the Prosecutor's authority to transmit case files to domestic jurisdictions, including to Rwanda, is sound both in law and policy. However, there are critics who question whether such transfers and transmissions should be supported as a matter of policy. The criticism of the policy are focused on, for example, the possibility that trials will not comply with fair trial standards, that courts will impose the death penalty, and, that Rwanda will mete out victor's justice. ${ }^{13}$ Because of these concerns, the critics of the policy of transfer of cases or transmissions, have recommended that "in addition to referring cases to Rwanda courts,

10) A. Marong, C.C. Jalloh and D.M. Kinnecome, Concurrent Jurisdiction at the ICTR: Should the Tribunal Refer Cases to Rwanda? (2007) in Human Rights to International Criminal Law Studies in honour of an African jurist: Judge Laity Kama, Emmanuel Decaux (ed.), pp. 59-201 (Leiden: Martinus Nijhoff Brill, 2007).

11) H.B. Jallow, Prosecutorial Discretion and International Criminal Justice, Journal of International Criminal Justice 3, 145-161 (2005).

12) A. Obote Odora, Case Selection and Prioritization Criteria at the International Criminal Tribunal, Morten Bergsmo (ed.) Criteria for Prioritizing and Selecting Core International Crimes Cases; Forum for International Criminal and Humanitarian Law (FICHL), pp. 41-54 (Oslo: International Peace Research Institute (PRIO), 2009).

13) A. Marong, C.C. Jalloh and D.M. Kinnecome, Concurrent Jurisdiction at the ICTR: Should the Tribunal Refer Cases to Rwanda? (2007) in Human Rights to International Criminal Law Studies in honour of an African jurist: Judge Laity Kama, Emmanuel Decaux (ed.), supra note 10, p. 186. 
the Prosecutor may request Trial Chambers to refer a case under indictment to another State under Rule 11 bis, or transfer a case not under indictment to another state on his own initiative. ${ }^{14}$ The argument is grounded on the theory that victor's justice and bias make transfer to other jurisdictions more attractive, especially in cases involving genocide-era officials. ${ }^{15}$ The argument is persuasive and the Prosecutor is alive to the issues.

In addition to conducting negotiations with Rwanda, the Prosecutor, since 2004 continues to have diplomatic engagement with relevant States with a view to securing their cooperation and to accept cases referred to their jurisdictions by the Chambers or to accept investigatory case files transmitted by the Prosecutor. In pursuit of this policy, the Prosecutor travelled to most countries in Africa, Europe, and North America while the Deputy Prosecutor also travelled to a number of countries including South Africa, Australia and New Zealand, seeking cooperation and support for Rule 11 bis transfers and cases transmitted by the Prosecutor. ${ }^{16}$ Due primarily to financial constraints, lack of adequate legal frameworks, or both, all African countries requested by the Prosecutor did not offer to receive and prosecute persons transferred under Rule 11 bis or transmitted by the Prosecutor. On the other hand, in Europe, a few states did volunteer. ${ }^{17}$

Due to the Prosecutor's policy of seeking out States that are willing and adequately prepared to prosecute serious violations of international crimes, to date, 60 case files have been transmitted by the Prosecutor to domestic jurisdictions. ${ }^{18}$

In preparation for the filing of Rule 11 bis motions for transfer of cases to Rwanda, the OTP held a series of meetings with the officials from the office of Rwanda's Prosecutor General at Kigali and Arusha. ${ }^{19}$ After these discussions between the OTP and Rwanda, but still recognizing that Rwanda's legal framework, among other things, may need further improvement, the Prosecutor nonetheless decided to file some Rule 11 bis requests intended to find out from the Chambers whether the legal framework in Rwanda has sufficiently improved to

\footnotetext{
14) Ibid., p. 199.

15) Ibid., pp. 199-200.

16) As Senior Legal Advisor and Special Assistant to the Prosecutor (2004-2007), I accompanied the Prosecutor and was present in many of the meetings at which the Prosecutor requested for support of these States.

17) Belgium, Canada, Finland, Norway and New Zealand, among others, agreed to cooperate with the Prosecutor and to prosecute persons transmitted to their jurisdictions or arrested in their respective countries. There have since been prosecution of persons arrested in States where they either sought asylum, or were illegal resident and the Prosecutor provided investigatory case files. See also A. Obote Odora, Genocide on Trial - Normative effects of the Rwanda tribunal's jurisprudence, Development Dialogue 55, pp. 145-150 (Uppsala: Dag Hammarskjöld Foundation, 2011).

18) Communication between the author and Mr. Murtaza Jaffer, Special Assistant to the Prosecutor on 10 February 2012.

19) From 2007, the author as Chief of Appeals and Legal Advisory Division, chairperson of the Rule 11 bis Committee and one of the Prosecuting Counsels in all the Rule 11 bis proceedings conducted a series of meetings with Rwanda and other States under consideration as possible candidates for Rule 11 bis transfers.
} 
permit transfers of cases to that country. The first of a series of motions were filed by the Prosecutor in 2005 and were subsequently all denied by Trial and Appeals Chambers. ${ }^{20}$ However, two cases were successfully transferred to France. ${ }^{21}$ Both accused were resident in France at the time the Prosecutor's applications were filed.

In denying the Prosecutor's requests for transfer of cases from the Tribunal to Rwanda, the Trial and Appeals Chambers provided a number of reasons suggesting why Rwanda was unsuitable. On the other hand, the OTP continued to have discussions with Rwanda and to improve conditions on the ground, including legal reforms. Rwanda cooperated with the Prosecutor by working closely with an internal prosecutorial Rule 11 bis committee. The Prosecutor organised training for the Rwandan prosecutors while the Chambers worked closely with the Rwanda judiciary through organizing, for example, joint seminars for the staff of the Rwanda judiciary and the Tribunal. The Registry collaborated with the Rwanda Registry in conducting seminars on issues that included protection of witnesses, rights of the accused and the security of the Defence teams including defence witnesses. Rwanda also introduced new legislation to meet the demands of the Tribunal on the one hand, and to improve the quality of justice rendered to its people beyond the scope of the Rule 11 bis applications. Rwanda therefore embarked on a wide range reform of the justice sector well beyond the requirements of Rule 11 bis. However, the Prosecutor continued to face challenges in his requests for transfer of cases. These challenges are discussed below.

20) See Prosecutor v. Yussuf Munyakazi, Decision on the Prosecutor's Request for Referral of the Case to the Republic of Rwanda, Case No. ICTR-97-36-R11bis, Trial Chamber (28 May 2008); Prosecutor v. Yussuf Munyakazi, Decision on the Prosecution's Appeal against Decision on Referral under Rule 11bis, Case No. ICTR-97-36-R11bis, Appeals Chamber (8 October 2008); Prosecutor v. Kanyarukiga, Decision on the Prosecutor's Request for Referral to the Republic of Rwanda, Case No. ICTR-2002-78-R11bis, Trial Chamber (6 June 2008), Prosecutor v. Kanyarukiga, Decision on the Prosecutor's Appeal against Decision on Referral under Rule 11bis, Case No. ICTR-02-78-R11bis, Appeals Chamber (30 October 2008); Prosecutor v. Jean Baptiste Gatete, Prosecutor's Request for the Referral of the Case of Jean-Baptiste Gatete to Rwanda pursuant to Rule 11bis of the Tribunal's Rules of Procedure and Evidence, Case No. ICTR-2000-61-I, Trial Chamber (28 November 2007); Prosecutor v. Idelphonse Hategekimana, Decision on Prosecutor's Request for Referral of the Case of Ildephonse Hategekimana to Rwanda, Case No. ICTR-00-55B-R11bis, Trial Chamber (19 June 2008), Prosecutor v. Idelphonse Hategekimana, Decision on Prosecutor's Appeal for Request under Rule 11bis, Case No. ICTR-00-55B-Rule 11bis, Appeals Chamber (4 December 2008); Prosecutor v. Michael. Bagaragaza, Decision on the Prosecution Motion for Referral to the Kingdom of Norway, Case No. ICTR-2005-86-R11bis, Trial Chamber (19 May 2006), Prosecutor v. Michael. Bagaragaza, Decision on Rule 11bis Appeal, Case No. ICTR-05-86-AR11bis, Appeals Chamber (30 August 2006) and Prosecutor v. Michael Bagaragaza, Decision on Prosecutor's Request for Referral of the Indictment to the Kingdom of Netherlands, Case No. ICTR-2005-86-11bis, Trial Chamber (13 April 2007) and Prosecutor v. Michael Bagaragaza, Decision on Prosecutor's Extremely Urgent Motion for Revocation of the Referral to the Kingdom of Netherlands pursuant to Rule 11bis(F) and Rule 11 bis(G), Case No. ICTR-2005-86-11bis, Trial Chamber (17 August 2007).

21) Prosecutor v. Wenceslas Munyeshyaka, Decision on the Prosecutor's Request for the Referral of Munyeshyaka's Indictment to France, Case No. ICTR-2005-87-I, Trial Chamber (20 November 2007); Prosecutor v. Laurent Bucyibaruta, Decision on the Prosecutor's Request for the Referral of Laurent Bucyibaruta's Indictment to France, Case No. ICTR-2005-85-I, Trial Chamber (20 November 2007). 


\section{An Overview of Rule 11 bis Jurisprudence}

With the exception of the successful transfer of Munyeshyaka and Bucyibaruta to France, all the Prosecutor's Rule 11bis requests to Rwanda, Norway and The Netherlands were denied by differently composed Chambers. While the decisions will be discussed in greater depth below, as a general matter, the judges concluded that Rwanda's legal system did not have the structural mechanism in place to render a fair trial to those defendants. On the other hand, the Chambers also determined that Norway and The Netherlands lacked a legal framework which criminalizes the conduct of the accused and provides an adequate penalty structure.

As the Prosecutor's primary target for transfer of cases is Rwanda, the Prosecutor pressed Rwanda to fast track reforms in the justice sector. After Rwanda made several justice sector reforms, including the construction of a prison that meets international standards at Mpanga, several miles from Kigali, and specially constructed cells at the 1930 Kigali Prison for accused attending trials at the High Court in Kigali, the Prosecutor again filed three more applications seeking transfer to Rwanda. ${ }^{22}$ The differently composed Trial Chambers deferred two of the three applications pending the decision of the third application, namely, Uwinkindi. ${ }^{23}$

Based on its decision in Uwinkindi, the Appeals Chamber was convinced, having regard to the legal framework in that jurisdiction, capacity building efforts to improve the legal system in Rwanda and the arrangement made by the Prosecutor for monitoring of trials in Rwanda, that the accused would have a fair trial in Rwanda. ${ }^{24}$

Before green light was given to enable transfers from the Tribunal to Rwanda in Uwinkindi, the Chamber had to be satisfied with two issues central to the rejection of the Prosecutor's requests under Rule 11bis. The first of these issues related to whether domestic courts have jurisdiction to try the international crimes contained in the Tribunal's Statute. The second concern was whether the domestic courts can provide a fair trial to an accused. These two broad issues subsumed several other related concerns, for example, whether there were adequate penalty provisions, provisions for protection of defence witnesses, free and

\footnotetext{
22) Prosecutor v. Charles Sikubwabo, Scheduling Order, Case No. ICTR-95-ID-R11bis, Trial Chamber (17 January 2011) and Prosecutor v. Fulgence Kayishema, Scheduling Order, Case No. ICTR-01-67R11bis. Trial Chamber (17 January 2011), and Prosecutor v. Jean-Bosco Uwinkindi, Prosecutor's Request for the Referral of the case of Jean-Bosco Uwinkindi to Rwanda pursuant to Rule 11bis of the Tribunal's Rule of Procedure and Evidence, Case No. ICTR-2001-75-I, Trial Chamber (4 November 2010).

23) Prosecutor v. Jean-Bosco Uwinkindi, Prosecutor's Request for the Referral of the case of Jean-Bosco Uwinkindi to Rwanda pursuant to Rule 11bis of the Tribunal's Rule of Procedure and Evidence, Case No. ICTR-2001-75-I, Trial Chamber (4 November 2010).

24) Jean Uwinkindi v. The Prosecutor, Decision on Uwinkindi's Appeal Against the Referral of his case to Rwanda and Related Motions, Case No. ICTR-01-75-AR11bis, Appeals Chamber (16 December 2011).
} 
unfettered movement of defence counsels and their support staff, and the capability to monitor the fairness of the trials. In this section, I evaluate the Trial and Appeals Chambers' jurisprudence on these issues under the headings jurisdiction and fair trials.

\subsection{Jurisdiction}

Rule 11 bis(A) contemplates possible referral to either the State where the crimes occurred, the State of the accused's arrest, or any other State having jurisdiction and being willing and adequately prepared to accept such a case. ${ }^{25}$ In most of the cases involving transfer to Rwanda, it is undisputed that Rwanda has jurisdiction as the State in whose territory the crimes were committed. Therefore, Rwandan courts are assumed to have personal jurisdiction over the accused charged with crimes committed on Rwandan territory, pursuant to Article 6 of the Rwandan Penal Code of $1977 .{ }^{26}$ To this extent, it may be noted that even in cases where the referral request is to a State in whose territory the crimes were committed, pursuant to Rule 11 bis(A)(i), such a State's willingness and preparedness to accept such a referral must also be considered. ${ }^{27}$ The same legal consideration is necessary prior to referral to a State which may assume jurisdiction after the accused is arrested in its territory. According to the Appeals Chamber, the Tribunal has no power to order a State to accept a transferred case, since a jurisdiction's willingness and capacity to accept a referred case is an explicit pre-requisite for any referral to a domestic jurisdiction. ${ }^{28}$ It is therefore submitted that a State's willingness and preparedness to accept a referral is central to a Trial Chamber's analysis of any such request.

A State's willingness to accept transfer of a case is often acknowledged by a Chamber on the provision of correspondence from the authorities of the State addressed to the Prosecutor of the Tribunal indicating such willingness. ${ }^{29}$ This

\footnotetext{
25) Prosecutor v. Michel Bagaragaza, Decision on Rule 11 bis Appeal, Case No. ICTR-05-86-AR11bis, Appeals Chamber (30 August 2006), para. 8.

26) Prosecutor v. Yussuf Munyakazi, Decision on the Prosecutor's Request for Referral of the Case to the Republic of Rwanda, Case No. ICTR-97-36-R11bis, Trial Chamber (28 May 2008), para. 16; Prosecutor v. Kanyarukiga, Decision on the Prosecutor's Request for Referral to the Republic of Rwanda, Case No. ICTR-2002-78-R11bis, Trial Chamber (6 June 2008), para. 9; Prosecutor v. Idelphonse Hategekimana, Decision on Prosecutor's Request for Referral of the Case of Ildephonse Hategekimana to Rwanda, Case No. ICTR-00-55B-R11bis, Trial Chamber (19 June 2008), para. 17.

27) Prosecutor v. Idelphonse Hategekimana, Decision on Prosecutor's Request for Referral of the Case of Ildephonse Hategekimana to Rwanda, Case No. ICTR-00-55B-R11bis, Trial Chamber (19 June 2008), para. 7, citing Prosecutor v. Stankovic, Decision on Rule 11bis Referral Case, No. IT-96-23/2-AR11bis, Appeals Chamber (1 September 2005), para. 40.

28) Prosecutor v. Stankovic, Decision on Rule 11bis Referral Case, No. IT-96-23/2-AR11bis, Appeals Chamber (1 September 2005), para. 40.

29) Prosecutor v. Laurent Bucyibaruta, Decision on the Prosecutor's Request for the Referral of Laurent Bucyibaruta's Indictment to France, Case No. ICTR-2005-85-I, Trial Chamber (20 November 2007), para. 7; Prosecutor v. Kanyarukiga, Decision on the Prosecutor's Request for Referral to the Republic of
} 
does not usually pose a problem, since the request for referral is often filed only after the Prosecutor has had discussions with the concerned State authorities on their willingness and preparedness to accept such a case. If, however, it is the State that would like the Prosecutor to file a request before the Chamber to order a referral to its jurisdiction, the obligation is on the State to demonstrate to the Prosecutor's satisfaction that she has jurisdiction. The Prosecutor will then make the application and preferably advise the State to request the Chamber grant it permission to participate in the proceedings as an amicus. It is for the court, based on current jurisprudence, to decide on whether that State has jurisdiction.

However, with regard to the adequacy of the preparedness of a State to assume jurisdiction over a case, a more detailed analysis is conducted by a Trial Chamber. It considers as part of the assessment of its preparedness if the concerned State has a legal framework which criminalizes the conduct of the accused and provides an adequate penalty structure. ${ }^{30}$

A Trial Chamber must first be satisfied that there is an adequate legal framework which criminalizes the accused's conduct so that the allegation can be duly tried and determined. ${ }^{31}$ It has been recognized that the Chamber is not the competent authority to decide in any binding way which law is to be applied by a State court if the case is transferred. That is a matter within the competence of the courts of the concerned State. ${ }^{32}$ However, since the Tribunal has concurrent jurisdiction with national authorities to prosecute "serious violations of international humanitarian law" pursuant to Article 8 of the Tribunal's Statute, the Chamber may only refer cases to such jurisdictions where the State will charge and convict for those international crimes listed in its Statute. ${ }^{33} \mathrm{~A}$ Trial Chamber is therefore authorised to make this determination pertaining to the nature of the crimes for which the accused may be tried in the national jurisdiction.

It may be noted, in this context, that the Trial Chamber in Bagaragaza found that Norway did not have subject matter jurisdiction over the crimes of genocide, complicity in genocide and conspiracy to commit genocide as charged in the Indictment, since it only criminalized homicide. The Chamber held that the domestic crime of homicide was significantly different in its elements and gravity from the crime of genocide. ${ }^{34}$ This was upheld by the Appeals Chamber. While

Rwanda, Case No. ICTR-2002-78-R11bis, Trial Chamber (6 June 2008), para. 7; Prosecutor v. Idelphonse Hategekimana, Decision on Prosecutor's Request for Referral of the Case of Ildephonse Hategekimana to Rwanda, Case No. ICTR-00-55B-R11 bis, Trial Chamber (19 June 2008), para. 13.

30) Prosecutor v. Michel Bagaragaza, Decision on Rule 11bis Appeal, Case No. ICTR-05-86-AR11bis, Appeals Chamber (30 August 2006), para. 9.

31) Prosecutor v. Kanyarukiga, Decision on the Prosecutor's Request for Referral to the Republic of Rwanda, Case No. ICTR-2002-78-R11bis, Trial Chamber (6 June 2008), para. 11.

32) Ibid.

33) Prosecutor v. Michel Bagaragaza, Decision on Rule 11bis Appeal, Case No. ICTR-05-86-AR11bis, Appeals Chamber (30 August 2006), para. 16.

34) Prosecutor v. Michel Bagaragaza, Decision on the Prosecution Motion for Referral to the Kingdom of Norway, Case No. ICTR-2005-86-R11bis, Trial Chamber (19 May 2006), para. 16. 
the Appeals Chamber agreed with the Prosecution's submission that the authorities of the referral State need not necessarily proceed under their laws against each act or crime in the indictment in the same manner as the Prosecution would have before the Tribunal, the Chamber held that the legal characterization and protected legal values for the crimes of genocide and homicide were different, and thereby such referral could not take place. ${ }^{35}$ The Chamber further held that it could not sanction referral of the case to a jurisdiction for trial where the conduct could not be charged as a serious violation of international humanitarian law. ${ }^{36}$

For similar reasons, the decision to refer the Bagaragaza case to the Netherlands was revoked once it was established by a decision of a district court in The Hague that Dutch courts did not have the jurisdiction to prosecute the Accused for genocide, and that their jurisdiction over the war crimes count in the Indictment was uncertain at the most. ${ }^{37}$ Similarly, appropriate consideration was given to the fact that French courts have jurisdiction over acts of genocide or crimes against humanity, prior to authorising such referrals in Munyeshyaka and Bucyibaruta. ${ }^{38}$

Trial Chambers have been satisfied that Rwanda has subject matter jurisdiction over the crimes charged in the indictments against the respective accused, based on the 2007 Transfer Law which provides for prosecution "only for crimes falling within the jurisdiction of the Tribunal". Further, Rwanda has also ratified several international conventions, including the Genocide Convention of 1948, which have since been incorporated into national law and carry considerable weight. ${ }^{39}$

It is interesting to note that as part of their consideration of an adequate legal framework, Trial Chambers are also given to analysing if modes of participation under national law are similar in substance to those found in the ICTR Statute. While it has been found that Rwandan law contains modes of participation similar to Article 6(1) of the ICTR Statute, ${ }^{40}$ the Hategekimana Trial Chamber was

\footnotetext{
35) Prosecutor v. Michel Bagaragaza, Decision on Rule 11 bis Appeal, Case No. ICTR-05-86-AR11bis, Appeals Chamber (30 August 2006), para. 17.

36) Ibid., para. 18.

37) Prosecutor v. Michael Bagaragaza, Decision on Prosecutor's Extremely Urgent Motion for Revocation of the Referral to the Kingdom of Netherlands pursuant to Rule 11 bis (F) and Rule 11 bis $(\mathrm{G})$, Case No. ICTR-2005-86-11bis, Trial Chamber (17 August 2007), paras. 11-12.

38) Prosecutor $v$. Wenceslas Munyeshyaka, Decision on the Prosecutor's Request for the Referral of Munyeshyaka's Indictment to France, Case No. ICTR-2005-87-I, Trial Chamber (20 November 2007), paras. 11-15; Prosecutor v. Laurent Bucyibaruta, Decision on the Prosecutor's Request for the Referral of Laurent Bucyibaruta's Indictment to France, Case No. ICTR-2005-85-I, Trial Chamber (20 November 2007), paras. $11-15$.

39) Prosecutor v. Gaspard Kanyarukiga, Decision on the Prosecutor's Request for Referral to the Republic of Rwanda, Case No. ICTR-2002-78-R11bis, Trial Chamber (6 June 2008), paras. 16-18; Prosecutor $v$. Idelphonse Hategekimana, Decision on Prosecutor's Request for Referral of the Case of Ildephonse Hategekimana to Rwanda, Case No. ICTR-00-55B-R11bis, Trial Chamber (19 June 2008), paras. 16-17.

40) Prosecutor v. Gaspard Kanyarukiga, Decision on the Prosecutor's Request for Referral to the Republic of Rwanda, Case No. ICTR-2002-78-R11bis, Trial Chamber (6 June 2008), para. 21; Prosecutor v.
} 
not satisfied that there was an adequate legal framework under Rwandan law to hold the Accused liable for superior responsibility, similar to Article 6(3) of the Statute. ${ }^{41}$ This constituted one of the grounds for the Chamber's refusal of the referral. However, as Professor Schabas correctly observed, this conclusion is erroneous because Rwanda has legislation recognising the concept of superior responsibility in its 1996 Organic Law, which was then replaced in its 2004 Organic Law. ${ }^{42}$ The Prosecution raised the Trial Chamber's failure to consider Rwanda's inclusion of superior responsibility as one of its grounds of appeal in its submissions to the Appeals Chamber in the Hategekimana appeal. ${ }^{43}$ The Appeals Chamber accepted the Prosecutor's submission on this ground but dismissed the appeal on other grounds.

It is also worthwhile to mention at this juncture that the Munyakazi Trial Chamber also considered whether the position of the accused in a crime committed during the 1994 events made it an appropriate case for referral. The Chamber, while acknowledging Prosecutorial discretion in selecting cases for possible transfer to national jurisdictions, recalled that the Tribunal is mandated under Security Council Resolutions 1503(2003) and 1534(2004) to transfer cases involving intermediate and low-rank accused to competent national jurisdictions. ${ }^{44}$ The Chamber then found that since the Accused was an Interahamwe leader largely limited to the Cyangugu préfecture, he neither had a rank of military significance, nor any official political role, thereby making it an appropriate case for referral. ${ }^{45}$ However, it is submitted that the position of the accused is not mentioned as a criteria in Rule 11 bis and has a bearing on neither the consideration of adequate legal framework nor appropriate penalty structure. This Munyakazi analysis appears to have been derived solely from the language of the Security Council Resolutions. However, unlike the Rules of the ICTY which specifically require the Chamber to consider the gravity of the crimes charged and the level of respon-

Idelphonse Hategekimana, Decision on Prosecutor's Request for Referral of the Case of Ildephonse Hategekimana to Rwanda, Case No. ICTR-00-55B-R11bis, Trial Chamber (19 June 2008), para. 18.

41) Prosecutor $v$. Idelphonse Hategekimana, Decision on Prosecutor's Request for Referral of the Case of Ildephonse Hategekimana to Rwanda, Case No. ICTR-00-55B-R11bis, Trial Chamber (19 June 2008), para. 19.

42) W. Schabas, Transfer and Extradition of Genocide Suspects to Rwanda, presented at a London Conference on The Extradition of Rwandese Genocide Suspects to Rwanda: Issues and Challenges, hosted by REDRESS and African Rights, 1 July 2008, pp. 9-10. The relevant provision as cited by Schabas (at p. 10) is as follows: "The fact that any of the acts aimed at by this organic law has been committed by a subordinate, does not free his or her superior from his or her criminal responsibility if he or she knew or could have known that his or her subordinate was getting ready to commit this act or had done it, and that the superior has not taken necessary and reasonable measures to punish the authors or prevent that the mentioned act be not committed when he or she had the means."

43) Prosecutor v. Yussuf Munyakazi, The Prosecutor's Appeal, Case No. ICTR-97-36-R11bis, Appeals Chamber (filed on 18 August 2008), paras. 11-27.

44) Prosecutor v. Yussuf Munyakazi, Decision on the Prosecutor's Request for Referral of the Case to the Republic of Rwanda, Case No. ICTR-97-36-R11bis, Trial Chamber (28 May 2008), para. 9.

45) Ibid., paras. 13-14. 
sibility of the accused following the Security Council resolutions, ${ }^{46}$ the ICTR Rules do not require this analysis. Further, none of the other ICTR Trial Chambers who have considered referral applications have engaged in such analysis.

The second prong of the analysis of an appropriate legal framework of a national jurisdiction pertains to that of an adequate penalty structure. The non-imposition of the death penalty is a pre-requisite for any referral under Rule 11 bis $(\mathrm{C})$. This assumes special significance in the Rwandan context, where the death penalty was not only excluded from application to transfer cases from the Tribunal, ${ }^{47}$ but also eliminated altogether from Rwandan law. ${ }^{48}$ The Trial Chambers therefore have had little problem in accepting the abolition of the death penalty in Rwanda as fulfilling one of the criteria for a successful Rule 11 bis referral. ${ }^{49}$

Even after the abolition of the death penalty in Rwanda, there are, however, considerable discussions in the Tribunal's decisions on the issue of the applicable punishment in Rwandan law. Although the Rules of Procedure and Evidence do not require it, the Trial Chambers have imposed an additional 'judge-made' condition for referrals, i.e., a consideration whether the penalty structure of the State legal system provides an appropriate punishment for the offences with which the Accused is charged. It may, however, be argued that concerns of appropriate punishment impact on the accused's right to fair trial, which is a factor to be considered under Rule 11bis. This appears to have been the approach of the Trial Chamber in Kanyarukiga..$^{50}$ Whether required or not, pursuant to Rule 11 bis, it must be noted that the issue of the appropriate punishment upon conviction was of some preoccupation to all Trial Chambers which have so far considered referral requests to Rwanda. More importantly, this issue was advanced as one reason to deny the referrals in all cases except in the recent case of Jean Bosco Uwinkindi.

In the context of Rwandan law, the issue of adequate penalty concerns the relationship between two Rwandan legislations - the March 2007 Organic Law concerning transfer of cases from the ICTR and excluding the death penalty for such cases, and the July 2007 Organic Law abolishing the death penalty altogether in Rwanda. The July 2007 Organic Law however mentions that the death

\footnotetext{
46) Rule 11bis(C), of the ICTY Rules of Procedure and Evidence.

47) Organic Law concerning transfer of cases to the Republic of Rwanda from the International Criminal Tribunal for Rwanda and from other States, Official Gazette of the Republic of Rwanda, Year 46, Special Issue of 19 March 2007, Article 21.

48) Organic Law No. 31/2007 of 25/07/2007 relating to the abolition of the death penalty, Official Gazette of the Republic of Rwanda, Year 46, Special Issue of 25 July 2007.

49) Prosecutor v. Yussuf Munyakazi, Decision on the Prosecutor's Request for Referral of the Case to the Republic of Rwanda. Case No. ICTR-97-36-R11bis, Trial Chamber (28 May 2008), para. 24; Prosecutor v. Gaspard Kanyarukiga, Decision on the Prosecutor's Request for Referral to the Republic of Rwanda, Case No. ICTR-2002-78-R11bis, Trial Chamber (6 June 2008), para. 25; Prosecutor v. Idelphonse Hategekimana, Decision on Prosecutor's Request for Referral of the Case of Ildephonse Hategekimana to Rwanda, Case No. ICTR-00-55B-R11 bis, Trial Chamber (19 June 2008), paras. 26-27.

50) Prosecutor v. Gaspard Kanyarukiga, Decision on the Prosecutor's Request for Referral to the Republic of Rwanda, Case No. ICTR-2002-78-R11bis, Trial Chamber (6 June 2008), paras. 94-96.
} 
penalty would be replaced with 'life imprisonment with special provisions' - a phrase that has been interpreted to include detention in isolation.

Although the Prosecution and the Republic of Rwanda disputed that the "special provision" clause would not be applicable under the Transfer Law and thus solitary confinement would not be allowed, ${ }^{51}$ all Trial Chambers found that if the respective Accused in the case was transferred to Rwanda and if convicted, they could be subject to life imprisonment in isolation. ${ }^{52}$ In reaching their conclusion, the Chambers were persuaded by the fact that there was genuine ambiguity in the relationship between the two laws, and subsequently in the issue of which law would ultimately prevail. Although the Transfer Law may be considered as the lex specialis with its provisions prevailing in the event of any inconsistency with any other legislation, the Death Penalty Law was the lex posterior, thereby repealing all provisions contrary to it. ${ }^{53}$

The existence of this ambiguity between the two laws was also endorsed by the Appeals Chamber in Munyakazi, which recognised the possibility that Rwandan courts might hold that a penalty of life imprisonment in isolation would apply to such transferred cases pursuant to the Death Penalty Abolition Law. ${ }^{54}$ Some scholars have sought to distinguish between the word 'isolation' used in the legislation and solitary confinement, the former referring to some form of administrative segregation where persons sentenced to life imprisonment for genocide would be held in a prison environment similar to maximum security, apart from the rest of the detainee population. ${ }^{55}$ However, the arguments have not persuaded the Trial and Appeals Chambers that the interpretation successfully reconciles the ambiguity in the provisions in the Death Penalty Law vis-à-vis a penalty of life imprisonment in isolation.

\subsection{Fair Trial}

A Trial Chamber is required to be satisfied that the accused will receive a fair trial in the courts of the referral State, prior to ordering the referral of a case to that

\footnotetext{
51) Ibid., para. 94

52) Prosecutor v. Yussuf Munyakazi, Decision on the Prosecutor's Request for Referral of the Case to the Republic of Rwanda, Case No. ICTR-97-36-R11bis, Trial Chamber (28 May 2008), para. 28; Prosecutor v. Gaspard Kanyarukiga, Decision on the Prosecutor's Request for Referral to the Republic of Rwanda, Case No. ICTR-2002-78-R11bis, Trial Chamber (6 June 2008), para. 96; Prosecutor v. Idelphonse Hategekimana, Decision on Prosecutor's Request for Referral of the Case of Ildephonse Hategekimana to Rwanda, Case No. ICTR-00-55B-R11 bis, Trial Chamber (19 June 2008), para. 25.

53) Prosecutor v. Gaspard Kanyarukiga, Decision on the Prosecutor's Request for Referral to the Republic of Rwanda, Case No. ICTR-2002-78-R11bis, Trial Chamber (6 June 2008), para. 96; Prosecutor v. Idelphonse Hategekimana, Decision on Prosecutor's Request for Referral of the Case of Ildephonse Hategekimana to Rwanda, Case No. ICTR-00-55B-R11bis, Trial Chamber (19 June 2008), para. 23.

54) Prosecutor v. Yussuf Munyakazi, Decision on the Prosecution's Appeal against Decision on Referral under Rule 11bis, Case No. ICTR-97-36-R11bis, Appeals Chamber (8 October 2008)., para. 20.

55) Schabas, W, 'Transfer and Extradition of Genocide Suspects to Rwanda', supra, note 42, p. 15.
} 
jurisdiction. ${ }^{56}$ In their determination of the fair trial requirement, the Chambers are guided by, inter alia, the criteria suggested in Article 20 of the Tribunal's Statute which lists the minimum guarantees for ensuring the right to fair trial. Taking the example of Rwanda, its Constitution ("the basic law") contains a separate chapter on human rights guarantees, including the right to non-discrimination and equality before the law (Articles 11 and 16), right to physical and mental integrity (Article 15), deprivation of liberty and the right to information of charges (Article 18); the presumption of innocence, right to fair and public hearing and access to courts (Article 19); non-retroactive application of criminal laws (Article 20); and the judiciary as the guardian of rights and freedoms (Article 44). ${ }^{57}$ In its 2007 Transfer Law, Rwanda imported rights similar to those stipulated in Article 20 of the Tribunal's Statute. ${ }^{58}$ Rwanda is also a party to the International Covenant on Civil and Political Rights ("ICCPR") and the African Charter on Human and Peoples' Rights ("ACHR"). 59

The Trial Chambers have been consistent in accepting that the Rwandan legal system generally mirrors the right to fair trial, as enshrined in Article 20 of the Tribunal's Statute. However, the issue that has been of some concern to the differently constituted Chambers is whether these guarantees in the law are effectively realised in practice. ${ }^{60}$ Although the Prosecution argued that the Chamber is not required to look beyond the relevant legislation in its determination, ${ }^{61}$ the Trial Chambers have been reluctant to confine themselves to such an analysis alone. Instead, they have considered all relevant information which they feel may be reasonably necessary to satisfy the Chambers that the accused will receive a fair trial in the national jurisdiction, including the actual prevailing practice in Rwanda on fair trial. ${ }^{62}$

The following issues pertaining to fair trial have thus been examined by the Chambers in this light, but not in any particular order: independence, impartiality and capacity of the Rwandan judiciary; presumption of innocence of the

\footnotetext{
56) Rule $11 b i s(\mathrm{C})$ of the ICTR Rules of Procedure and Evidence.

57) Ibid., para. 28.

58) Ibid., para. 29.

59) Prosecutor v. Gaspard Kanyarukiga, Decision on the Prosecutor's Request for Referral to the Republic of Rwanda, Case No. ICTR-2002-78-R11bis, Trial Chamber (6 June 2008), para. 27.

60) Prosecutor v. Gaspard Kanyarukiga, Decision on the Prosecutor's Request for Referral to the Republic of Rwanda, Case No. ICTR-2002-78-R11bis, Trial Chamber (6 June 2008), para. 31; Prosecutor v. Idelphonse Hategekimana, Decision on Prosecutor's Request for Referral of the Case of Ildephonse Hategekimana to Rwanda, Case No. ICTR-00-55B-R11bis, Trial Chamber (19 June 2008), para. 36.

61) Prosecutor v. Idelphonse Hategekimana, Decision on Prosecutor's Request for Referral of the Case of Ildephonse Hategekimana to Rwanda, Case No. ICTR-00-55B-R11bis, Trial Chamber (19 June 2008), para. 34.

62) Prosecutor v. Gaspard Kanyarukiga, Decision on the Prosecutor's Request for Referral to the Republic of Rwanda, Case No. ICTR-2002-78-R11bis, Trial Chamber (6 June 2008), para. 33; Prosecutor v. Idelphonse Hategekimana, Decision on Prosecutor's Request for Referral of the Case of Ildephonse Hategekimana to Rwanda, Case No. ICTR-00-55B-R11bis, Trial Chamber (19 June 2008), para. 35.
} 
accused; double jeopardy; conditions of detention pending or during trial; and the right to an effective defence, including availability of counsel, legal aid and the availability and protection of witnesses. It may be noted that a significant number of issues relating to the practice of fair trial in Rwanda have withstood close scrutiny by the Chambers, and do not pose a problem as such for referral. However, the one fair trial issue concerning the availability and protection of defence witnesses in Rwanda has been a ground for the denial of such referral requests.

All differently constituted Trial Chambers in Munyakazi, Kanyarukiga and Hategekimana denied the referral request on the ground that the accused will not be able to call witnesses from both inside and outside Rwanda under the same conditions as those of the Prosecution, thereby adversely affecting the accused's right to fair trial. ${ }^{63}$ In reaching their conclusions, the Chambers relied on amici submissions by Human Rights Watch ("HRW") and International Criminal Defence Attorneys Association ("ICDAA") on the state of witness availability and protection in Rwanda. The Trial Chambers were persuaded to some extent by the fact that due to the expansive interpretation given to "genocidal ideology" laws in Rwanda, potential Defence witnesses residing within Rwanda may refrain from testifying for an accused. ${ }^{64}$ The Trial Chambers also noted that since several witnesses resided outside Rwanda, the practical unavailability of subpoenas due to Rwanda's failure to concretise mutual assistance between States in criminal matters, and the unfeasibility of using video-link exclusively to hear Defence witnesses would render the trial unfair. ${ }^{65}$ Eventually, it was the totality of the circumstances that made the different Chambers deny the referral request on this ground.

The Appeals Chamber while considering the Munyakazi appeal observed in respect of witnesses within Rwanda that " $[\mathrm{t}]$ he information available to the Trial Chamber demonstrates that regardless of whether their fears are well-founded, witnesses in Rwanda may be unwilling to testify for the Defence as a result of the fear that they may face serious consequences, including threats, harassment, torture, arrest, or being killed." ${ }^{66}$ It appears therefore that the Appeals Chamber was largely deferential to the agreements between the different Trial Chambers of the

\footnotetext{
63) Prosecutor v. Yussuf Munyakazi, Decision on the Prosecutor's Request for Referral of the Case to the Republic of Rwanda, Case No. ICTR-97-36-R11bis, Trial Chamber (28 May 2008), para. 66; Prosecutor v. Gaspard Kanyarukiga, Decision on the Prosecutor's Request for Referral to the Republic of Rwanda, Case No. ICTR-2002-78-R11bis, Trial Chamber (6 June 2008), paras. 73 and 81; Prosecutor v. Idelphonse Hategekimana, Decision on Prosecutor's Request for Referral of the Case of Ildephonse Hategekimana to Rwanda, Case No. ICTR-00-55B-R11bis, Trial Chamber (19 June 2008), para. 71.

64) Prosecutor v. Gaspard Kanyarukiga, Decision on the Prosecutor's Request for Referral to the Republic of Rwanda, Case No. ICTR-2002-78-R11bis, Trial Chamber (6 June 2008), paras. 71-73.

65) Ibid., paras. 76-81.

66) Prosecutor v. Yussuf Munyakazi, Decision on the Prosecution's Appeal against Decision on Referral under Rule 11bis, Case No. ICTR-97-36-R11bis, Appeals Chamber (8 October 2008), para. 37.
} 
subjective fears of witnesses, and the use of the phrase "regardless of whether their fears are well founded" suggests that despite the possibility of different conclusions, the Appeals Chamber was reluctant to disturb the earlier finding on the issue. This is particularly of some concern to the OTP, since the Trial Chambers were heavily influenced by information provided by NGOs and other organisations in reaching their conclusion. Such information is often a result of field studies, and is different from testimonial and other documentary evidence admitted before the Chambers after being subjected to the usual rigors and scrutiny of cross-examination. Further, it appears that considerable weight was given to the Trial Chamber's assessment of the subjective fears of witnesses, in the absence of an objective standard. This poses certain difficulties since it makes it unclear what the State can do to address these concerns involving the subjective fears of witnesses. It may also be added that the Appeals Chamber was not persuaded that the Trial Chamber erred in finding that the witness protection service was understaffed and lacked resources. ${ }^{67}$

The Appeals Chamber found with respect to the witnesses from outside Rwanda that " $[\mathrm{t}]$ here was sufficient information before the Trial Chamber that, despite the protections available under Rwandan law, many witnesses residing outside Rwanda would be afraid to testify in Rwanda." ${ }^{68}$ In its examination of the possibility of video-link testimony to hear witnesses from outside Rwanda, the Chamber held that it was not a completely satisfactory solution given the preference for direct witness testimony. Further, it would also occasion a violation of the principle of equality of arms if the majority of Defence witnesses testify by video-link, while the majority of Prosecution witnesses testify in person. ${ }^{69}$

On the issue of independence of the judiciary, the Munyakazi Trial Chamber found that the Rwandan Government's past actions had a tendency to pressure the judiciary. ${ }^{70}$ The Trial Chamber extensively quoted the negative reactions of the Rwandan authorities to both the indictments issued by the Spanish and French Judges against former members of the Rwanda Patriotic Front ("RPF"). ${ }^{71}$ It found that this would be of particular concern in a judicial system that provides for trial by a single judge who would be particularly susceptible to pressure. ${ }^{72}$ According to HRW, at least twenty-five Rwandan high-ranking judicial officials, judges, prosecutors and lawyers currently or formerly active informed its researchers in 2005, 2006 and 2007, that the Rwandan courts are not independent. ${ }^{73}$ The

67) Ibid., para. 38 .

68) Ibid., para. 40.

69) Ibid., para. 42.

70) Prosecutor v. Yussuf Munyakazi, Decision on the Prosecutor's Request for Referral of the Case to the Republic of Rwanda, Case No. ICTR-97-36-R11bis, Trial Chamber (28 May 2008), paras. 40-48.

71) Ibid., paras. 42-45.

72) Ibid., para. 39.

73) Prosecutorv. YussufMunyakazi, Brief of Human Rights Watch as Amicus Curiae in Opposition to Rule 11 bis Transfer, Case No. ICTR-1997-36-I, Trial Chamber (17 March 2008), para. 51. 
judges also viewed as apposite Rwanda's interrupted cooperation with the Tribunal following dismissal of an indictment and release, with prejudice to the Prosecutor, of Barayagwiza. ${ }^{74}$

On the Prosecutor's request for Review and Reconsideration following the dismissal of the indictment and release of Barayagwiza, Prosecutor Del Ponte argued that her ability to continue with prosecutions and investigations depends on the government of Rwanda and that, unless the Appellant is tried, the Rwanda government will no longer "be involved in any manner". ${ }^{75}$ In its decision, the Appeals Chamber noted that during the hearing of 22 February 2000 in Arusha,

Prosecutor Carla Del Ponte made a statement regarding the reaction of the government of Rwanda to the decision. She stated that "the government of Rwanda reacted very seriously in a tough manner to the decision of 3 November 1999." Later, the Attorney General of Rwanda appearing as a representative of the Rwanda Government, in his submission as "amicus curiae" to the Appeals Chamber, openly threatened the non co-operation of the peoples of Rwanda with the Tribunal if faced with an unfavourable decision by the Appeals Chamber on the Motion of Review. ${ }^{76}$

On the submission by the Attorney General of Rwanda, the Appeals Chamber stressed that the Tribunal is an independent body, whose decisions are based solely on justice and law. If its decisions in any case should be followed by non cooperation, that consequence would be a matter for the Security Council. ${ }^{77}$ However, the Appeals Chamber proceeded to allow the Prosecutor's appeal based on "new facts." 78

In its deliberations, the Trial Chamber was alive to the importance of the requirement that an independent tribunal must be independent of the executive, the parties and the legislature. The Chamber found that the criteria for judicial independence includes the manner of appointment of judges, the existence of guarantees against outside pressure and the appearance of independence. ${ }^{79}$ However, it was concerned that although the Law in Rwanda contains guarantees of judicial independence, the practice "has been somewhat troubling." 80

The Munyakazi Trial Chamber linked the above concerns to trial of genocide cases by a single judge in Rwanda. It considered that it would be "too much to expect one individual to be able to resist the pressure of a State whose past prac-

\footnotetext{
74) Jean-Bosco Baraygwiza v. Prosecutor, Decision, Case No. ICTR-97-19-AR72, Appeals Chamber (3 November 1999)

75) Jean-Bosco Baraygwiza v. Prosecutor, Decision (Prosecutor's Request for Review and Reconsideration), Case No. ICTR-97-19-AR72, Appeals Chamber (31 March 2000), para. 24.

76) Ibid., para. 34.

77) Ibid.

78) Ibid., paras. 74-75.

79) Prosecutor v. Yussuf Munyakazi, Decision on the Prosecutor's Request for Referral of the Case to the Republic of Rwanda, Case No. ICTR-97-36-R11bis, Trial Chamber (28 May 2008), para. 37.

80) Ibid., para. 40.
} 
tice has shown interference with judicial decisions." ${ }^{81}$ It also linked the single judge's susceptibility to outside pressure to the fact that although the case would go to the Supreme Court composed of three judges, this Tribunal cannot reexamine the witnesses or make its own factual findings. ${ }^{82}$ The Trial Chamber concluded that a single judge's findings of fact cannot be reviewed by the Supreme Court unless there has been a miscarriage of justice. ${ }^{83}$

However, the Appeals Chamber reversed this finding on the ground that the Barayagwiza incident was nine years ago and the Tribunal has since acquitted five accused without Rwanda suspending its cooperation with the Tribunal ${ }^{84}$ It further cited Rwanda's continued cooperation with the Tribunal and dismissed the Trial Chamber's finding on Rwanda's reaction to the indictments issued by foreign judges because it did not see this as any indication of how Rwanda would react to decisions of its own courts. ${ }^{85}$ From the Appeals Chamber decision in Munyakazi, it is implicit that Rwanda is presumed to have judicial independence until there is more information to demonstrate actual interference. ${ }^{86}$

Another relevant consideration on fair trial issues is the working condition for Defence teams. The Trial Chamber in Kanyarukiga found that there have been incidents involving harassment of defence counsel representing accused persons charged with genocide before ordinary Rwandan courts. ${ }^{87} \mathrm{HRW}$ gave various examples of defence counsel that faced threats, harassment and prosecution following their defence of an accused person. ${ }^{88}$ It further found that Defence teams have previously faced difficult working conditions in Rwanda, particularly noting the difficulty they faced in obtaining documents from Rwanda and meeting detainees in Rwanda. ${ }^{89}$ Both the Trial and Appeals Chambers concluded that although these obstacles, while not sufficient, in and of themselves, to prevent transfer, coupled with other factors, indicated that the working conditions of the defence may be difficult in Rwanda and that this has a bearing on fair trial issues. ${ }^{90}$

81) Ibid., para. 46.

82) Ibid., para. 47.

83) Ibid., para. 48.

84) Prosecutor v. Yussuf Munyakazi, Decision on the Prosecution's Appeal against Decision on Referral under Rule 11bis, Case No. ICTR-97-36-R11bis, Appeals Chamber (8 October 2008), para. 28.

85) Ibid.

86) Ibid., para. 29.

87) Prosecutor v. Gaspard Kanyarukiga, Decision on the Prosecutor's Request for Referral to the Republic of Rwanda, Case No. ICTR-2002-78-R11bis, Trial Chamber (6 June 2008), para. 61; Prosecutor v. Yussuf Munyakazi, Brief of Human Rights Watch as Amicus Curiae in Opposition to Rule 11 bis Transfer, Case No. ICTR-1997-36-I, Trial Chamber (17 March 2008), para. 69.

88) Prosecutor v. Yussuf Munyakazi, Human Rights Watch Brief as Amicus Curiae in Opposition to Rule 11 bis Transfer, Case No. ICTR-1997-36-I, Trial Chamber (17 March 2008), paras. 70-72.

89) Prosecutor v. Gaspard Kanyarukiga, Decision on the Prosecutor's Request for Referral to the Republic of Rwanda, Case No. ICTR-2002-78-R11bis, Trial Chamber (6 June 2008), para. 62.

90) Prosecutor v. Gaspard Kanyarukiga, Decision on the Prosecutor's Appeal against Decision on Referral under Rule 11bis, Case No. ICTR-02-78-R11bis, Appeals Chamber (30 October 2008), para. 21. 
The Appeals Chamber in Kanyarukiga was concerned that while Article 15 of the Law on Transfer provides for the right of Defence Counsels and their support staffs to enter and move freely within Rwanda, including the freedom from search, seizure, arrest or detention in the performance of their legal duties, it is silent on the issues of obtaining documents from Rwandan authorities or visiting detainees. ${ }^{91}$ It indicated that it's finding on the difficult working conditions for Defence Teams would have been different had Article 15 of the Transfer Law contained specific provisions enabling Defence teams to obtain documents from Rwandan authorities.

Further, HRW submitted that the Rwandan witness protection service cannot provide protection to neither prosecution nor defence witnesses. ${ }^{92}$ It argued that this service was established in 2005 but is currently understaffed, is exclusively funded by foreign donors and refers all cases of threats to witnesses or victims to local police and political authorities. ${ }^{33}$

HRW also submitted that witnesses would not testify on behalf of the defence for fear of being accused of harbouring "genocidal ideology," which term HRW claims, has been manipulated by government officials to encompass a broad spectrum of ideas, including ideas perceived as being in opposition to the policies of the current Rwandan Government. ${ }^{94} \mathrm{HRW}$ submitted extensively on Rwanda's witness protection service in its Amicus Brief. It made reference to interviews it had with senior Rwandan Government officials and painted a bleak picture of the service. It concluded that "the Rwandan witness protection service cannot provide protection to witnesses, whether of the prosecution or the defence." 95 At Trial, the Prosecutor's request to cross-examine researchers of HRW who prepared the report was denied by the Trial Chamber.

In its deliberations, the Appeals Chamber made reference to approximately ten cases documented by HRW where Defence witnesses who testified at the Tribunal were subsequently arrested, re-arrested, subjected to worse conditions of incarceration or harassed following their return to Rwanda. ${ }^{96}$ The Appeals Chamber also made reference to four cases documented by HRW of persons who refused, out of fear, to testify in defence of persons whom they knew to be innocent of charges against them. ${ }^{97}$

\footnotetext{
91) Ibid.

92) Prosecutor v. Yussuf Munyakazi, Human Rights Watch Brief as Amicus Curiae in Opposition to Rule 11 bis Transfer, Case No. ICTR-1997-36-I, Trial Chamber (17 March 2008), para. 27.

93) Ibid.

94) Ibid., paras. 30-34.

95) Ibid., para. 27.

96) Prosecutor v. Yussuf Munyakazi, Decision on the Prosecutor's Request for Referral of the Case to the Republic of Rwanda. Case No. ICTR-97-36-R11bis, Trial Chamber (28 May 2008), para. 56; Prosecutor v. Yussuf Munyakazi, Brief of Human Rights Watch as Amicus Curiae in Opposition to Rule 11 bis Transfer, Case No. ICTR-1997-36-I, Trial Chamber (17 March 2008), para. 97.

97) Prosecutor v. Yussuf Munyakazi, Decision on the Prosecution's Appeal against Decision on Referral under Rule 11bis, Case No. ICTR-97-36-R11bis, Appeals Chamber (8 October 2008), para. 56;
} 
The weight of evidence against transfer of cases to Rwanda seems to have been exacerbated by the Appeals Chamber finding that defence witnesses would be afraid to avail themselves of Rwanda's witness protection service because it is administered by the Prosecutor-General's Office and threats to witnesses are reported to the Police, ${ }^{98}$ an institution the witnesses do not seem to trust. The Appeals Chamber further expressed concerns that Rwanda's witness protection service is understaffed with only sixteen employees serving the whole country, as per HRW Brief.99

The Appeals Chamber also found that accused persons in cases transferred to Rwanda would face "significant difficulties" in securing the attendance of witnesses who reside outside Rwanda to an extent that would jeopardize their fair trial rights. ${ }^{100}$ It found that most Defence witnesses reside abroad ${ }^{101}$ and that most witnesses that live in the Diaspora would be afraid to testify in Rwanda. ${ }^{102}$ These concerns were compounded by the Rwandan Minister of Justice's statement, as quoted by the media, that witnesses from abroad who testified in Rwanda would be arrested. ${ }^{103}$

Even though the Appeals Chamber noted the ability of Rwanda to arrange for witnesses to testify as a result of having concluded several mutual assistance agreements with a number of countries and Rwanda's ability to provide video-link services, it was not convinced that this was a satisfactory solution, considering that it is preferable to hear direct witness testimony. ${ }^{104}$ The Appeals Chamber

Prosecutor v. Yussuf Munyakazi, Brief of Human Rights Watch as Amicus Curiae in Opposition to Rule 11 bis Transfer, Case No. ICTR-1997-36-I, Trial Chamber (17 March 2008), para. 37.

98) Prosecutor v. Gaspard Kanyarukiga, Decision on the Prosecutor's Appeal against Decision on Referral under Rule 11 bis, Case No. ICTR-02-78-R11bis, Appeals Chamber (30 October 2008), para. 27; Prosecutor v. Yussuf Munyakazi, Decision on the Prosecution's Appeal against Decision on Referral under Rule 11 bis, Case No. ICTR-97-36-R11bis, Appeals Chamber (8 October 2008), para. 55.

99) Prosecutor v. Yussuf Munyakazi, Decision on the Prosecution's Appeal against Decision on Referral under Rule 11 bis, Case No. ICTR-97-36-R11bis, Appeals Chamber (8 October 2008), para. 62; Prosecutor v. Yussuf Munyakazi, Brief of Human Rights Watch as Amicus Curiae in Opposition to Rule 11 bis Transfer, Case No. ICTR-1997-36-I, Trial Chamber (17 March 2008), paras. 27, 85-87.

100) Prosecutor v. Gaspard Kanyarukiga, Decision on the Prosecutor's Appeal against Decision on Referral under Rule 11bis, Case No. ICTR-02-78-R11bis, Appeals Chamber (30 October 2008), para. 33. Prosecutor v. Yussuf Munyakazi, Decision on the Prosecution's Appeal against Decision on Referral under Rule 11 bis, Case No. ICTR-97-36-R11bis, Appeals Chamber (8 October 2008), para. 40.

101) Prosecutor v. Yussuf Munyakazi, Decision on the Prosecution's Appeal against Decision on Referral under Rule 11bis, Case No. ICTR-97-36-R11bis, Appeals Chamber (8 October 2008), para. 63.

102) Prosecutor v. Gaspard Kanyarukiga, Decision on the Prosecutor's Appeal against Decision on Referral under Rule 11bis, Case No. ICTR-02-78-R11bis, Appeals Chamber (30 October 2008), para. 31, See also Prosecutor v. Yussuf Munyakazi, Brief of Human Rights Watch as Amicus Curiae in Opposition to Rule 11 bis Transfer, Case No. ICTR-1997-36-I, Trial Chamber (17 March 2008), para. 38 (HRW indicated that it carried out interviews with two dozens Rwandans in the Diaspora and none of them was willing to testify in Rwanda).

103) Prosecutor v. Yussuf Munyakazi, Decision on the Prosecution's Appeal against Decision on Referral under Rule 11bis, Case No. ICTR-97-36-R11bis, Appeals Chamber (8 October 2008), para. 61.

104) Prosecutor v. Gaspard Kanyarukiga, Decision on the Prosecutor's Appeal against Decision on Referral under Rule 11bis, Case No. ICTR-02-78-R11bis, Appeals Chamber (30 October 2008), para. 33. 
concluded that this would violate the principle of equality of arms since the majority of Defence witnesses would be heard by video-link, while the majority of Prosecution witnesses would be heard directly. ${ }^{105}$

However, the Appeals Chamber also noted that there is no judicial system that can guarantee absolute witness protection. ${ }^{106}$ Having found that witnesses in Rwanda face harassment, torture, threats, and sometimes death; that the Prosecutor General's Office administers the witness program and threats are reported to the police, the Appeals Chamber concluded that this does not necessarily render the witness protection service inadequate. ${ }^{107}$ Rather, the Appeals Chamber's conclusion is that witnesses would be afraid to avail themselves to the Police who are supervised by the office of the Prosecutor General.

To ensure State compliance with fair trials, Trial Chambers require that trials are monitored. If fair trial standards are not met, the transfer may be revoked.

On monitoring trials, the Appeals Chamber noted that the provisions of Rule 11 bis $(\mathrm{D})(\mathrm{iv})$ and Rule 11bis(F) are problematic because the decision to send monitors and to consider revocation lies in the sole discretion of the Prosecutor. ${ }^{108}$ While acknowledging that the African Center for Human and Peoples' Rights (ACHPR) had the necessary qualifications to monitor the trials of cases referred to Rwanda and that Article 20 of the Transfer Law obliges Rwanda to promptly surrender an accused to the Tribunal if a referral order is revoked, the Appeals Chamber found that these remedies did not solve the problem related to availability of defence witnesses. ${ }^{109}$

The ICDAA raised the concern that requiring the Prosecutor to choose and send observers to monitor Rwandan trials of persons formerly charged by his

\footnotetext{
Prosecutor v. Yussuf Munyakazi, Decision on the Prosecution's Appeal against Decision on Referral under Rule 11bis, Case No. ICTR-97-36-R11bis, Appeals Chamber (8 October 2008), para. 42; Prosecutor v. Idelphonse Hategekimana, Decision on Prosecutor's Appeal for Request under Rule 11bis, Case No. ICTR-00-55B-Rule 11bis, Appeals Chamber (4 December 2008) para. 26.

105) Prosecutor v. Gaspard Kanyarukiga, Decision on the Prosecutor's Appeal against Decision on Referral under Rule 11bis, Case No. ICTR-02-78-R11bis, Appeals Chamber (30 October 2008), para. 33.

106) Prosecutor v. Yussuf Munyakazi, Decision on the Prosecution's Appeal against Decision on Referral under Rule 11bis, Case No. ICTR-97-36-R11bis, Appeals Chamber (8 October 2008), para. 38.

107) Prosecutor v. Gaspard Kanyarukiga, Decision on the Prosecutor's Appeal against Decision on Referral under Rule 11bis, Case No. ICTR-02-78-R11bis, Appeals Chamber (30 October 2008), para. 27; Prosecutor v. Yussuf Munyakazi, Decision on the Prosecution's Appeal against Decision on Referral under Rule 11 bis, Case No. ICTR-97-36-R11bis, Appeals Chamber (8 October 2008), para. 38.

108) Prosecutor v. Gaspard Kanyarukiga, Decision on the Prosecutor's Appeal against Decision on Referral under Rule 11bis, Case No. ICTR-02-78-R11bis, Appeals Chamber (30 October 2008), para. 38; Prosecutor v. Idelphonse Hategekimana, Decision on Prosecutor's Appeal for Request under Rule 11bis, Case No. ICTR-00-55B-Rule 11bis, Appeals Chamber (4 December 2008), para. 29; Prosecutor v. Yussuf Munyakazi, ICDAA Brief as Amicus Curiae in Opposition to Rule 11 bis Transfer, Case No. ICTR-199736-I, Trial Chamber (17 March 2008), paras. 128-129.

109) Prosecutor v. Gaspard Kanyarukiga, Decision on the Prosecutor's Appeal against Decision on Referral under Rule 11bis, Case No. ICTR-02-78-R11bis, Appeals Chamber (30 October 2008), para. 38. Ibid., Prosecutor v. Idelphonse Hategekimana, Decision on Prosecutor's Appeal for Request under Rule 11bis, Case No. ICTR-00-55B-Rule 11bis, Appeals Chamber (4 December 2008), para. 29.
} 
office defeats the very purpose of having monitors. ${ }^{110}$ In ICDAA's opinion, "monitoring should be carried out by independent observers who represent the interests of all interested parties, including, but not limited to, the Prosecution, the Defence, Victims, the Judiciary, and civil society" and these observers "should be appointed by an independent organization, not the Prosecutor." ${ }^{111}$

The Appeals Chamber indicated its displeasure with the status quo in the appointment of monitors. The Chamber's concern was that the current Rules do not allow the Accused to trigger the remedies of sending monitors and seeking revocation. ${ }^{112}$ The Chamber appears to be supportive of amendment to the current Rules. However, as a practical matter, amendment of Rule 11 bis(D)(iv) and Rule $11 b i s(\mathrm{~F})$ to allow Defence to have a say in appointing a monitor would be problematic. First, only permanent judges of the Tribunal, without ad litem judges, vote on the amendment of the Rules, and only when there is a quorum. Currently, there are insufficient numbers of permanent judges to form a quorum. For the permanent judges to amend the Rules to reduce the numbers required for a quorum, they must, in the first place, raise a quorum. Second, as the workload of the Tribunal shifts to the Mechanism, it is unlikely the Council and the General Assembly will have incentives to appoint new permanent judges for the Tribunal. Persuading the two organs to appoint more permanent judges as the Tribunal moves towards closure is a difficult task. Third, the process of initiating amendment to the Rules commences with a proposed draft from the Chambers or from the OTP. The defence do not generally initiate drafts or participate in the discussion on the amendment of the Rules, save on the invitation of the President. Often, they are only invited to make a statement at the Plenary and then leave. ${ }^{113}$ The OTP may not be too keen to seek an amendment to Rule 11 bis(D) (iv) and Rule 11bis(F) which may result in undermining the authority of the Prosecutor to appoint monitors, particularly as ICDAA would prefer to take away that authority from the Prosecutor.

It is imperative that an acceptable solution to the triggering of the monitoring and revocation mechanisms that will be in existence long after the ICTR has closed its doors is found and an amendment thereof is sought. Such a solution, subject to resolving the quorum question, may include amending Rule 11 bis $(\mathrm{D})$ (iv) to allow a neutral office of the residual mechanism of the Tribunal, the

\footnotetext{
110) Prosecutor v. Yussuf Munyakazi, ICDAA Brief as Amicus Curiae in Opposition to Rule 11bis Transfer, Case No. ICTR-1997-36-I, Trial Chamber (17 March 2008), para. 129.

111) Ibid.

112) Prosecutor v. Gaspard Kanyarukiga, Decision on the Prosecutor's Appeal against Decision on Referral under Rule 11bis, Case No. ICTR-02-78-R11bis, Appeals Chamber (30 October 2008), para. 38.

113) The author was a member of the Rules Committee (2007-2010). The Defence became members of the Rules Committee only in 2009 with Mr. Otachi representing the Defence when Rule 71bis was discussed by the Committee. In principle he opposed the proposed adoption of Rule 71 bis. At the Plenary when Rule 71 bis was adopted - Rule 71bis regulates the preservation of evidence - the Defence's representative was not invited.
} 
ACHPR or a body mutually acceptable to the Prosecution and Defence to monitor the transferred cases on the application of either the Prosecutor or the Defence. This solution would also include amendment of Rule 11 bis $(\mathrm{F})$ to allow either the Prosecutor or the Defence to apply to the ACHPR to assess and invoke the revocation mechanism.

Last, but not least, is the question of finance. International criminal prosecution is an expensive undertaking. In the Rwandan referral cases, HRW correctly submitted that the Rwandan legal system may be unable to provide appropriate financial support to indigent accused, including facilitating defence teams' travel and investigations. ${ }^{114} \mathrm{HRW}$ further argued that although Rwanda undertook to provide US \$500 000 in the fiscal year 2008 to assist indigent persons transferred under Rule 11bis, it was skeptical about Rwanda's commitment to providing adequate funding and cited Rwanda's previous inability to pay the cost of legal assistance provided to indigent accused in Rwanda. ${ }^{115}$

ICDAA also took note of Article 13(6) of the Transfer Law which provides that "accused shall be entitled to counsel of his choice in any examination. In case he or she has no means to pay, he or she shall be entitled to a legal representation."116 However, it argued that while on paper Rwandan law includes some provisions guaranteeing legal assistance, the financial support is not adequate. ${ }^{117}$ It was concerned that it was not aware of a budget for travel and investigation for Defence teams in Rwanda for transferred cases. ${ }^{118}$ According to ICDAA, legal aid is generally problematic in Rwanda since in the regular court system, the law provides for public trials with the right to a defence but not at public expense. ${ }^{119}$

Overall, it is not only Rwanda that faces obstacles, including financial constraints, other States seeking to try accused persons for violations of international crimes who are arrested in their territories or referred to their domestic jurisdictions by the Tribunal or the Mechanism, will face similar legal and financial challenges in the investigation and prosecution of referred cases. The high cost of legal aid has been a matter of considerable public debate, even in developed countries such as the United Kingdom and the United States.

The Uwinkindi Appeals Chamber decision hopefully provides a timely benchmark for national jurisdictions that are willing and adequately prepared to receive, and to conduct further investigations for the purpose of prosecuting international crimes. However, the Prosecutor's diplomatic negotiations for the transfer of Rule 11 bis cases with African, North American and European States were

114) Prosecutor v. Yussuf Munyakazi, Human Rights Watch Brief as Amicus Curiae in Opposition to Rule 11 bis Transfer, Case No. ICTR-1997-36-I, Trial Chamber (17 March 2008), paras. 75-79.

115) Ibid., para. 76.

116) Prosecutor v. Yussuf Munyakazi, ICDAA Brief as Amicus Curiae in Opposition to Rule 11 bis Transfer, Case No. ICTR-1997-36-I, Trial Chamber (17 March 2008), para. 27.

117) Ibid., para. 34.

118) Ibid., para. 53.

119) Ibid., paras. 45-46. 
generally unsuccessful for two reasons. First, many States, particularly in Africa, did not have financial resources to support investigation and prosecution of international crimes. Second, for a variety of legal reasons, many States, including North American and European States, lacked a legal framework which criminalizes the alleged conduct of the accused and provides an adequate penalty structure as provided in the Tribunal's Statute. The applicability of the death penalty, for example, excludes many States from eligibility under Rule 11 bis. These challenges make it difficult to take advantage of the Uwinkindi decision and to transfer more cases under Rule 11 bis to other national jurisdictions but Rwanda.

\section{Uwinkindi Appeals Chamber Decision}

The Uwinkindi Appeals Chamber decision opens the way for transfers of more cases from the Tribunal to Rwanda, the country where the 1994 genocide was committed. The transfer of cases to Rwanda also complements the Tribunal's completion strategy by reducing the Tribunal's workload resulting in an orderly closure of the Tribunal. It also provides great opportunity for Rwandan victims and survivors, who may wish to participate in proceedings in person, to do so.

The Uwinkindi Appeals Chamber confirms the basic law on transfer of cases. It re-states that Rule 11 bis authorizes a designated Trial Chamber to refer a case to a competent national jurisdiction for trial if it is satisfied that the accused will receive a fair trial and that the death penalty will not be imposed or carried out. ${ }^{120}$ The Uwinkindi Appeals Chamber also states that in assessing whether a State is competent within the meaning of Rule 11 bis to accept the Tribunal's cases, a designated Trial Chamber must consider whether it has a legal framework which criminalizes the alleged conduct of the accused and provides an adequate penalty structure. ${ }^{121}$ This is consistent with the position taken by the Bagaragaza Appeals Chamber. $^{122}$

Additionally, the Uwinkindi Appeals Chamber underscored the point that the penalty structure within the State must provide an appropriate punishment for the offences for which the accused is charged, and conditions of detention must accord with international standards. ${ }^{123}$ The Appeals Chamber further emphasised that a Trial Chamber must also consider whether the accused will receive

\footnotetext{
120) Jean Uwinkindi v. The Prosecutor, Decision on Uwinkindi's Appeal Against the Referral of his case to Rwanda and Related Motions, Case No. ICTR-01-75-AR11bis, Appeals Chamber (16 December 2011), para. 22.

121) Ibid., para. 22.

122) Prosecutor v. Michael. Bagaragaza, Decision on Rule 11 bis Appeal, Case No. ICTR-05-86-AR11bis, Appeals Chamber (30 August 2006), para. 9.

123) Jean Uwinkindi v. The Prosecutor, Decision on Uwinkindi's Appeal Against the Referral of his case to Rwanda and Related Motions, Case No. ICTR-01-75-AR11bis, Appeals Chamber (16 December 2011), para. 22.
} 
a fair trial, including whether the accused will be accorded the rights set out in Article 20 of the Tribunal's Statute. ${ }^{124}$

With regard to the merits of appeal under Rule 11bis, the Uwinkindi Appeals Chamber affirmed the ICTY Appeals Chamber case-law that a case can only be referred to another jurisdiction under Rule 11 bis when the crimes charged can be prosecuted in those jurisdictions as "serious violation of international humanitarian law" as the ICTY and ICTR Statutes envisage. ${ }^{125}$ The Appeals Chamber further recalled that the basis of the Tribunal's authority to refer cases to national jurisdictions flows from Article 8 of the Statute as affirmed in Security Council resolutions. ${ }^{126}$

However, even after the Prosecution has met the formal requirements under Rule 11 bis for the transfer of a case from the Tribunal to a domestic jurisdiction, the decision to transfer remains discretionary. ${ }^{127}$ The Appeals Chamber set out conditions under which, on an appeal against a Trial Chamber decision, the Appeals Chamber will intervene. The conditions are met if the Trial Chamber's decision:

- was based on a discernible error and, the burden is on the appellant to show that the Trial Chamber misdirected itself either as to the principle to be applied or as to the law which is relevant to the exercise of its discretion;

- gave weight to irrelevant considerations;

- failed to give sufficient weight to relevant considerations;

- or made an error as to the facts upon which it has exercised its discretion;

- Or that its decision was so unreasonable and plainly unjust that the Appeals Chamber is able to infer that the Trial Chamber must have failed to exercise its discretion properly." 128

The conditions outlined above by the Appeals Chamber suggest that a Trial Chamber enjoys a wide scope of discretion.

The Uwinkindi Appeals Chamber also confirmed that a Trial Chamber's authority extends to considering conditions of detention in a State seeking referral. Thus, in assessing the conditions of detention in a referral State, a designated Trial Chamber should ascertain whether the laws governing detention incorporate relevant international standards regarding the treatment of prisoners because conditions of detention are a relevant consideration in assessing the fairness of

124) Ibid., para. 22.

125) Ibid., paras. 16-18.

126) Prosecutor v. Michael. Bagaragaza, Decision on Rule 11bis Appeal, Case No. ICTR-05-86-AR11bis, Appeals Chamber (30 August 2006), para. 9.

127) Jean Uwinkindi v. The Prosecutor, Decision on Uwinkindi's Appeal Against the Referral of his case to Rwanda and Related Motions, Case No. ICTR-01-75-AR11bis, Appeals Chamber (16 December 2011), para. 23.

128) Ibid., para. 23. 
domestic criminal proceedings. It is therefore within the inherent authority of a Referral Chamber to extend monitoring to this aspect of the referred case. ${ }^{129}$ The Appeals Chamber further stated that in assessing the availability of defence witness testimony, a Referral Chamber's role is not to determine whether the witnesses' fears were well-founded, but instead to focus on the likelihood that the accused will be able to secure their appearance on his behalf under the same conditions as those testifying against him. In conclusion, the Appeals Chamber stated that it is permissible for a Referral Chamber to emphasize the need for adequate legal safeguards to address any subjective fears that might discourage witnesses from testifying. ${ }^{130}$

Although a Referral Chamber could reasonably deny referral notwithstanding the existence of this legal framework, largely due to the specific finding that the accused may face difficulties in securing the attendance of witnesses to the extent that it would prejudice his right to a fair trial, the Appeals Chamber held that it is equally within the discretion of a Trial Chamber to find that the ability to compel testimony is a factor which can be taken into account in addressing the subjective fears of defence witnesses. ${ }^{131}$ Other factors to consider, according to the Uwinkindi Appeals Chamber, are alternative means of securing testimony from witnesses from abroad, including, by means of deposition, remote testimony, or video-link. ${ }^{132}$ There is, however, one important caveat to the use of alternative means: it would be a violation of the principle of equality of arms if the majority of defence witnesses appeared by means substantially different from those of the Prosecution. ${ }^{133}$

A Referral Chamber also must satisfy itself that the State would supply defence counsel to an accused who cannot afford their own representation. ${ }^{134}$ However, once a Trial Chamber has learnt that there is financial support for that representation, a Referral Chamber is not obliged to inquire further or request an itemization of the State's budget. ${ }^{135}$ In cases where the Prosecution requests referral, it must demonstrate that the conditions set out in Rule 11 bis are met. ${ }^{136}$

The Uwinkindi Appeals Chamber further noted that, in satisfying itself that the trial in any referred case will be fair, a Referral Chamber may rely to a considerable degree on the monitoring mechanism provided by the Rule. Moreover, a Referral Chamber has the authority to dictate the scope of the monitoring and

\footnotetext{
129) Ibid., paras. 37-38.

130) Ibid., para. 61

131) Ibid., para. 64.

132) Ibid., para. 66.

133) Ibid., para. 67.

134) Ibid., para. 71.

135) Ibid., para. 71.

136) Ibid., para. 28.
} 
the frequency and nature of reporting. ${ }^{137}$ If the terms of the monitoring are not complied with, then the proceedings may be revoked. ${ }^{138}$

While not expressly provided for in the Rule, the Uwinkindi Appeals Chamber held that, as a general matter, the accused may have access to the monitoring reports submitted to the Tribunal, unless the President of the Tribunal determines that there is good cause to limit access. ${ }^{139}$

The jurisprudential development in the Uwinkindi Trial and Appeals Chamber decisions is positive, particularly as the accused will be tried in the country where the crimes were committed. The victims and survivors will also have the opportunity to participate in the proceedings even if only as spectators. However, one aspect of the Uwinkindi Appeals Chamber's decision is problematic and more substantial reasoning by the Appeals Chamber would have been of great benefit to all interested persons. This concern relates to Appeals Chamber interpretation of an ambiguity identified in Article 59 of the Rwanda Code of Criminal Procedure ("RCCP").

While it is conceded that Trial and Appeals Chamber need not provide detailed reasons for every issue or ground of appeal in their decisions, it is reasonable for the parties to the proceedings to expect a clear reasoning that underpins a court's decision, particularly on issues that the final decision revolves around. It is submitted that the interpretation of Article 59 of the RCCP is central to the case. It directly impacts on Appellant's rights to a fair trial. It is also important when viewed alongside its earlier decision in Munyakazi.

Article 59 of the RCCP provides that "[p] ersons against whom the prosecution has evidence to suspect that they were involved in the commission of an offence cannot be heard as a witness." ${ }^{40}$ The context in which Article 59 of the RCCP is applied is relevant and also central in determining whether it does not infringe on Appellant's rights to fair trial.

All parties can easily agree that millions of Rwandans were directly and indirectly involved in the 1994 genocide; a crime in which at least $10 \%$ of the population were reportedly killed. Some Rwandans were direct perpetrators 'working' alongside other co-conspirators. Other Rwandans aided and abetted the commission of the crimes with knowledge that the crime of genocide was being committed. Others were spectators who stood by and watched as their neighbours were slaughtered. Some Rwandans provided shelter and sanctuary to the perpetrators. These individuals are all potential witnesses either for the prosecution or for the defence. These individuals are also likely to be excluded from giving testimony for the defence under Article 59 of the RCCP. The impact of that

\footnotetext{
137) Ibid., para. 83 .

138) Ibid., para. 83.

139) Ibid., para. 85.

140) Law No.13/2004 of 17/5/2004 Relating to the Code of Criminal Procedure, O.G. Special No. 30/07/2004, Article 59.
} 
exclusion is to undermine Appellant's ability to present his case because the decision on whether or not to exclude a witness under Article 59 of the RCCP rests with the Prosecutor.

In reviewing Article 59 of the RCCP, the Trial Chamber identified six reasons why the provision was problematic and could negatively impact Appellant's fair trial rights:

\begin{abstract}
First, [the Trial Chamber noted that] it is not clear that this provision would permit the Accused to testify in his own defence. Second, as this provision allows the exclusion of a witness' $[\mathrm{s}$ ] evidence on the suspicion of the prosecutor rather than a legal ground, it violates the principle of the presumption of innocence. Third, the law provides no indication that the judge may override the prosecutor's indications that a witness may have participated in an offence. Fourth, the law does not specify the type of "offence" that might warrant exclusion of a witness. Fifth, because this provision would be applied in an arbitrary manner by the prosecutor, it could have a chilling impact on the willingness of the defence witnesses to testify. Finally, this article may be detrimental not only to the interests of the defence but to those of the prosecution, as many of the cases before this Tribunal rely on varying extents on the testimonies of accomplice witness. ${ }^{141}$
\end{abstract}

The Trial Chamber summarily dismissed the above concerns and stated that "it [the Trial Chamber] was confident that Article 59 of the RCCP would not be applied to any referred case." ${ }^{42}$ The Trial Chamber explained neither the reasoning leading to that conclusion nor articulated the underlying reasons for its 'confidence' that Article 59 of the RCCP will not negatively impact on the Appellant's rights to fair trial.

Further, the Trial Chamber asserted that Article 13(10) of the Transfer Law guarantees the right of an accused to obtain the attendance and examination of witnesses on his behalf under the same conditions as witnesses against him or her, and that Article 25 of the Transfer Law states that, in the event of an inconsistency between the Transfer Law and any other law, the provisions of the Transfer Law will prevail. ${ }^{143}$ This line of reasoning did not address the Appellants main ground of appeal. On the contrary, the Appellant had argued that there is ambiguity in the law and different courts acting reasonably may interpret the law differently, an issue the Trial Chamber did not address in its decision.

\footnotetext{
141) Jean Uwinkindi v. The Prosecutor, Decision on Uwinkindi's Appeal Against the Referral of his case to Rwanda and Related Motions, Case No. ICTR-01-75-AR11bis, Appeals Chamber (16 December 2011), para. 46.

142) Ibid., para. 47.

143) Prosecutor v. Jean-Bosco Uwinkindi, Prosecutor's Request for the Referral of the case of Jean-Bosco Uwinkindi to Rwanda pursuant to Rule 11 bis of the Tribunal's Rule of Procedure and Evidence, Case No. ICTR-2001-75-I, Trial Chamber (4 November 2010), para. 40. The Trial Chamber refers to Article 13(9) of the Transfer Law. This is a reference to the original text of the 2007 Transfer Law; however, Article 13 of the 2007 Transfer Law was amended by Article 2 of the 2009 Amendment. In light of this amendment, the relevant fair trial right guarantee mentioned by the Trial Chamber should be Article 13(10) and not Article 13(9) of the Transfer Law. Thus, all reference to Article 13(9) by the Trial Chamber is referenced Article 13(10) by the Appeals Chamber.
} 
On appeal, the Appellant's primary argument was that the Trial Chamber erred in finding that the combined operation of Articles 13(10) and 25 of the Transfer Law provides reasonable assurance that Article 59 of the RCCP would not be applied in his transfer case. The Appellant further submitted that the provisions of the Transfer Law are insufficient to overcome the impact of Article 59 of the RCCP on his right to a fair trial because, inter alia, the two instruments are not inconsistent. The Transfer Law is triggered only when there is an inconsistency between Article 59 of the RCCP and Articles 13(10) and 25 of the Transfer Law. Since there is no inconsistency between Article 59 and the two articles in the Transfer Law, the Appellant argued that he cannot benefit from Article 25 of the Transfer Law.

The Prosecution, however, argued that Article 59 of the RCCP would not be applied in a referred case because the primacy of the Transfer Law guarantees the right of the defence to obtain and examine witnesses under the same conditions as prosecution witnesses. The Prosecution further submitted that Article 59 of the RCCP does not in practice prevent the accused or accomplice from testifying. The Prosecution did not however address the question of inconsistency between Article 59 of the RCCP and Article 25 of the Transfer Law, the central argument of the Appellant. The Prosecution did not also address the Appellant's argument that Article 25 of the Transfer Law is triggered only when there is an inconsistency between Article 59 of the RCCP and any provision in the Transfer Law.

A reasonable interpretation of Article 59 of the RCCP may suggest that the article could bar the presentation of evidence by an accused or any defence witness who is suspected of involvement in an offence. However, the Appeals Chamber addressed this mischief in a circular manner. Without examining the reasoning of the Trial Chamber on why, after identifying six flaws in Article 59 of the RCCP, and without sufficient discussion on whether Articles 13(10) and 25 of the Transfer Law are inconsistent, the Appeals Chamber proceeded to conclude that the Trial Chamber interpreted Article 59 of the RCCP as being inconsistent with Article 13(10) of the Transfer Law and therefore inapplicable in any case transferred to Rwanda by the Tribunal pursuant to Article 25 of the Transfer Law. The Appeals Chamber went on to emphasise that, implicit in this ruling is the Trial Chamber's conclusion that, in light of the Transfer Law, the Appellant would not be precluded from presenting evidence of a witness suspected of involvement in an offence on his own behalf. In this respect, the Appeals Chamber concurred with the Trial Chamber that the Rules of the Tribunal guarantees an accused the right to appear as a "witness" in his own defence. ${ }^{144}$ The Appeals Chamber further noted that the parties before the Tribunal are permitted to, and often do, rely on accomplice witnesses or other witnesses who are suspected of being involved in the commission of the crimes. It is relevant to note that there is no provision in

144) Ibid., para. 50. 
the Statute or Rules of the Tribunal identical to Article 59 of the RCCP. Therefore, the fact that accomplice witnesses and other witnesses suspected of being involved in the commission of the crimes do testify before the Tribunal is not particularly relevant to an accused appearing before a High Court in Rwanda. The two situations, because of Article 59 of the RCCP, are not comparable.

Additionally, the Appeals Chamber conceded that the Transfer Law is not as clear as it could be in relation to the right of all parties to present evidence of witnesses without limitation in any referred case. The Appeals Chamber further noted that Article 59 of the RCCP is ambivalent as to whether the proscription it contains applies equally to witnesses called by the prosecution in Rwanda. Having noted these flaws, the Appeals Chamber nonetheless proceeded to pronounce itself "satisfied that it was within the discretion of the Trial Chamber to conclude that Article 59 of the RCCP would not be applied in any referred case and that the Transfer Law guaranteed the accused the requisite fair trial rights with regard to the presentation of witness evidence" 145 without further examining whether the Trial Chamber erred in the exercise of its discretion. Having summarily dismissed the point, the Appeals Chamber proceeded to take specific note of the previous order by the Trial Chamber for monitoring cases and recalled that should the interpretation of the Transfer Law set forth in the decision be proven incorrect, the Tribunal in any event retains the right to revoke the reference of the case to Rwanda court. ${ }^{146}$

It will never be known whether, if the Appeals Chamber had provided substantial reasons for its decision, it would have reached a different conclusion. What appears to be certain is that the Uwinkindi Appeals Chamber reasoning with respect to Article 59 of the RCCP was intended to pave way for a transfer to Rwanda. In a sense, the decision is a 'dry run'; or a 'trial-run' intended to test the judicial process in Rwanda with a view towards future transfer of cases to Rwanda depending on how the Rwanda judiciary handles the trial. In other words, it is a test case, and future transfers will depend on how Rwanda's judiciary handles the Uwinkindi trial.

The Uwinkindi Appeals Chamber approach is distinctly different from the Munyakazi Appeals Chamber when the Chamber was confronted with a similar issue with respect to ambiguity in the provisions relating to the Death Penalty Law vis-à-vis life imprisonment in isolation.

The existence of ambiguity between a penalty of life imprisonment in isolation and the Death Penalty Abolition Law was endorsed by the Appeals Chamber in Munyakazi, which recognised the possibility that Rwandan courts might hold that a penalty of life imprisonment in isolation would apply to such transferred

145) Ibid., para. 51.

146) Jean Uwinkindi v. The Prosecutor, Decision on Uwinkindi's Appeal Against the Referral of his case to Rwanda and Related Motions, Case No. ICTR-01-75-AR11bis, Appeals Chamber (16 December 2011), para. 52. 
cases pursuant to the Death Penalty Abolition Law. ${ }^{147}$ It is also possible that the Rwanda courts may take the view that life imprisonment in isolation means 'solitary confinement.' In Uwinkindi, however, the Appeals Chamber took the opposite position but without substantive persuasive reasons explaining its departure from Munyakazi, although it has the right to do so. It is a settled legal principle that an Appeals Chamber need not give reasons on every issue it decides. On the other hand, it enriches the jurisprudence whenever Appeals Chamber gives reasons for its decisions, particularly on important issues, as for example, that which confronted the Appeals Chamber in Munyakazi and Uwinkindi, and yet the Chambers reached different conclusions, notwithstanding that the issues were similar.

In Munyakazi, the Appeals Chamber denied the Prosecutor's request for the transfer of the case to Rwanda even after the Prosecutor provided a detailed plan for monitoring the case. The Prosecutor had argued that should the interpretation of the Transfer Law set forth in the decision be proven incorrect, the Tribunal in any event retains the right to revoke the reference of the case to Rwanda. The Prosecutor submitted that the presence of the monitors would remedy any problem that may arise. The Appeals Chamber rejected the submission and reached the conclusion that the monitoring was not sufficient to remedy the lacunae in the Transfer Law. Significantly, the Appeals Chamber noted that it is doubtful whether these guarantees in law are effectively realized in practice. The Appeals Chamber was therefore not persuaded that the monitoring of transferred cases requested by the Prosecutor could remedy any shortcomings in the interpretation of the Transfer Law with respect to the death penalty vis-à-vis imprisonment in isolation.

\section{Conclusion}

Overall, the Uwinkindi decision is important and positive. It is a departure from the Munyakazi, Kanyarukiga and Hategekimana decisions that denied the Prosecutor's Rule 11 bis requests. Uwinkindi also recognises an important principle in criminal trials. Where possible, an accused should be prosecuted in the country where the crimes are committed. By trying Appellant in Rwanda, the place where the crimes were allegedly committed, victims and survivors who wish to attend the proceedings will have the opportunity to do so. Additionally, the Uwinkindi decision acknowledges the legal reforms that have been made in a post-genocide Rwanda.

Reflecting on the decision, it is tempting to suggest that not much will change on the ground. There will be no floods of cases transferred to Rwanda for a

\footnotetext{
147) Prosecutor v. Yussuf Munyakazi, Decision on the Prosecution's Appeal against Decision on Referral under Rule 11bis, Case No. ICTR-97-36-R11bis, Appeals Chamber (8 October 2008), para. 20.
} 
number of legal and practical reasons. A core principle of Rule 11 bis is that a Referral Chamber cannot sanction referral of a case to a jurisdiction for trial where the conduct of the accused could not be charged as a serious violation of international humanitarian law as the Tribunal's statute envisages. The law of that State must also provide an adequate penalty structure. This condition potentially excludes all States that have not domesticated international crimes in their national law or still have the death penalty in their Statute books.

Second, a Referral Chamber must consider whether the law governing detention incorporates relevant international standards regarding the treatment of prisoners because conditions of detention are a relevant consideration in assessing the fairness of domestic criminal proceedings. Random readings of reports by Human Rights Watch or Amnesty International regularly condemn poor detention facilities is many States. Rwanda, but for detainees at Mpanga Prison and the special cells at the 1930 Kigali prison, is no exception.

Third, a Referral Chamber must satisfy itself that the State would supply Defence counsel to an accused who cannot afford their own representation. This includes providing appropriate financial support to indigent accused including facilitating defence teams' travels and investigations. Accused should also have the right to be represented by foreign counsels if he or she desires. In Rwanda, for the trials conducted in regular courts but not at the gacaca traditional courts, the law provides for public trials with right to defence but not at public expenses. Without international funding extended to Rwanda by the European Union and other donors under a special fund for the defence, Rwanda would have failed to meet this condition.

Fourth, accepting international experts to monitor the trial process is a condition the receiving State must comply with. It is necessary for the monitors to independently confirm that the trial meets international standards and threshold, particularly as set out in Article 20 of the Tribunal's Statute.

A number of States in Africa and elsewhere have not domesticated international crimes of genocide, crimes against humanity and war crimes in their national legislations. Many States also have the death penalty in their Statute books. These States will not qualify to receive and prosecute persons transferred under Rule 11 bis or transmitted by the Prosecutor. Similarly, States that do not comply with international standards on pre-trial and post-trial detentions, if the accused is convicted, do not qualify to receive transferred cases or investigatory case files transmitted by the Prosecutor. Additionally, a failure to provide legal representation to an indigent accused, at the public expense, will further undermine the State's ability to receive cases for further investigations and trial.

Considering the above issues individually or cumulatively, one realizes that the pool of possible States willing and adequately prepared to receive transferred cases or investigatory case files transmitted by the Prosecutor for trial is extremely limited. In the long run, Rwanda may remain the only viable alternative, subject to how it handles the seminal first transfer case: the Uwinkindi trial. 
In conclusion, and despite its limitation, the Uwinkindi decision is a step in the right direction. The tenacity of the OTP in continuing to re-apply to the Chambers for Rule 11 bis transfers after every denial is a testimony to the Prosecutor's commitment to ensure an orderly closure of the Tribunal under its completion strategy. In the absence of Rule 11bis transfers, the Mechanism will simply transform itself into a mini ICTR and will continue with trials for many years thus defeating its purpose as an institution created to conclude all trials within a limited period. To that extent, the roads ahead for further transfer of cases to other domestic jurisdictions demand extensive reforms in the justice sectors of States identified as possible recipients of Rule 11 bis transfers. As regards Rwanda, further Rule 11bis transfers may depend on how Uwinkindi's trial proceeds and that there will be no revocation for failure to meet international standards at the trial in Kigali. 